\title{
ANALISIS REGRESI DATA PANEL PADA KEMISKINAN PROVINSI ACEH TAHUN 2016-2020
}

\author{
Wahyudi \\ Institut Agama Islam Negeri Takengon \\ yudiwahyu204@gmail.com
}

\begin{abstract}
Poverty is one of the indicator of development welfare in a region. The higher the poverty rate of a region, indicate the lower the public development in the region. This study aims to model and determine the factors that influence poverty rate in Aceh province at 2016-2020. The analytical method used is panel data regression analysis with secondary data sources obtained from the Central Statistics Agency (BPS). The results show that the suitable model that fits to the poverty data of Aceh province in $2016-2020$ is a panel data regression model with a fixed effect (Fixed effect model). The factors that significantly effect to poverty are the human development index, resistance rate, and population growth rate with a high $\mathrm{R}$ squared value that is $97.14 \%$.
\end{abstract}

Keywords : Poverty, Panel Data Regression, Fixed Effect Model

\section{ABSTRAK}

Kemiskinan menjadi salah satu indikator kesejahteraan pembangunan disuatu daerah. Semakin tinggi tingkat kemiskinan suatu daerah maka akan mengindikasikan bahwa kualitas pembangunan masyarakat di daerah tersebut rendah. Penelitian ini bertujuan untuk memodelkan dan mengetahui faktor-faktor yang mempengaruhi kemiskinan di provinsi Aceh tahun 2016-2020. Metode analisis yang digunakan adalah analisis regresi data panel dengan sumber data sekunder yang diperoleh dari badan pusat statistika (BPS). Hasil penelitian menunjukkan bahwa model yang sesuai dengan data kemiskinan provinsi Aceh tahun 2016-2020 adalah model regresi data panel dengan pengaruh tetap (Fixed effect mode). Faktor-faktor yang signifikan mempengaruhi kemiskinan yaitu indek pembangunan manusia, angka kesakitan, dan laju pertumbuhan penduduk dengan nilai $\mathrm{R}$ squared yang tinggi sebesar $97.14 \%$.

Kata kunci : Kemiskinan, Regresi Data Panel, Fixed Effect Model 


\section{PENDAHULUAN}

Kemiskinan merupakan salah satu permasalahan ekonomi yang kompleks dan terus saja terjadi di berbagai wilayah di Indonesia. Kemiskinan tidak hanya terkait kondisi ekonomi akan tetapi terintegrasi dengan permasalahan sosial, budaya, agama, politik dan bidang aspek lainnya. Kondisi yang kompleks ini menyebabkan masalah kemiskinan menjadi penting dan terdesak untuk diberantas karena ini menjadi tolak ukur keberhasilan pembangunan ekonomi dan manusia di suatu daerah. Aceh merupakan salah satu provinsi yang memiliki dana APBD cukup tinggi setiap tahunnya secara nasional, namun tidak lantas menjadikan Aceh sebagai provinsi yang sejahtera (Andiny, 2017). Masalah kemiskinan di Aceh masih belum bisa teratasi dengan maksimal terlihat dari banyaknya jumlah penduduk miskin di provinsi ini dari tahun ketahun (BPS, 2020).

Angka persentase penduduk miskin yang tinggi di suatu daerah tentu saja akan menjadi beban besar pembangunan nasional, sehingga tugas pemerintah dalam mengatasinya pun akan semakin besar. Dalam rangka menekan angka kemiskinan yang tinggi, berbagai upaya telah dilakukan oleh pemerintah seperti Pemberian pelatihan kerja, Program Keluarga Harapan (PKH), Kredit Usaha Rakyat (KUR), Bantuan Langsung Tunai (BLT) dan berbagai hal lainnya. Namun faktanya kondisi kemiskinan di Indonesia khususnya provinsi Aceh masih masuk kedalam kelompok provinsi dengan tingkat kemiskinan yang patut mendapat perhatian khusus jika dibandingkan dengan kelompok provinsi lainnya (Ferezegia, 2018). Pemerintah masih perlu memikirkan langkah dan solusi yang terbaik untuk mengurangi masalah tingkat kemiskinan, baik secara regional maupun nasional.

Menurut Laporan Badan Pusat Statistika (BPS), tahun 2020 Aceh merupakan provinsi dengan persentase angka kemiskinan tertinggi se-Sumatera. Pada periode Maret 2020 persentase angka kemiskinan provinsi Aceh yaitu sebesar 14.99\% sedangkan periode september 2020 naik sebesar $0,44 \%$ menjadi $15,43 \%$ diatas rata-rata kemiskinan nasional. Angka ini sungguh sangat memprihatikan mengingat Aceh merupakan provinsi yang mendapatkan tambahan anggaran dana otonomi khusus (Otsus) dari pemerintah pusat untuk membangun daerahnya sesuai UndangUndang No. 35 Tahun 2008. Hal ini mengindikasikan bahwa program dan kebijakan pengentasan kemiskinan yang dilakukan oleh pemerintah Aceh khususnya masih memiliki kelemahan dan kendala dalam pelaksanaannya sehingga dibutuhkan suatu analisis yang tepat untuk memodelkan dan mengetahui faktor-faktor yang mempengaruhi permasalahan data kemiskinan ini. Salah satu metode yang dapat dilakukan untuk menganalisis permasalahan data kemiskinan adalah Analisis Regresi Data Panel. Analisis Regresi data panel sangat cocok untuk menganalisis dan memodelkan data kemiskinan yang multidimensi, sehingga diharapkan dapat menghasilkan informasi lebih mendalam dan menyeluruh terkait faktor-faktor apa yang mempengaruhi kemiskinan di Provinsi Aceh. 


\section{METODE PENELITIAN}

\subsection{Sumber Data dan Variabel Penelitian}

Penelitian ini menggunakan data mengenai kemiskinan provinsi Aceh yang merupakan data sekunder yang diperoleh dari Badan Pusat Statistik (BPS) Provinsi Aceh. Objek dalam penelitian ini adalah 23 Kabupaten/Kota yang berada di wilayah provinsi Aceh. Variabel yang digunakan dalam penelitian ini yaitu variabel respon $(Y)$ dan empat variabel penjelas $(\mathrm{X})$. Adapun pemilihan variabel yang digunakan pada penelitian ini didasari oleh beberapa penelitian yang dirangkum dalam Pulungan (2016).

Tabel 1 : Variabel Penelitian

\begin{tabular}{cl}
\hline Variabel & \multicolumn{1}{c}{ Keterangan } \\
\hline $\mathrm{Y}$ & Persentase penduduk miskin/Tingkat kemiskinan \\
$\mathrm{X}_{1}$ & Indek Pembangunan Manusia (IPM) \\
$\mathrm{X}_{2}$ & Tingkat Pengangguran Terbuka (TPT) \\
$\mathrm{X}_{3}$ & Laju Pertumbuhan Penduduk (LPP) \\
$\mathrm{X}_{4}$ & Angka Kesakitan (AK) \\
\hline
\end{tabular}

\subsection{Metode Analisis Regresi Data Panel}

Metode yang digunakan dalam penelitian ini adalah metode analisis deskriptif dan kuantitatif. Metode analisis deskriptif dalam penelitian digunakan untuk mendeskripsikan dan mempermudah interpretasi data dalam bentuk tabel atau grafik. Metode analisis kuantitatif yang digunakan adalah regresi data panel untuk melihat pengaruh beberapa variabel yang dapat mempengaruhi tingkat kemiskinan. Analisis regresi panel data yaitu regresi menggunakan data berupa cross section dengan 23 Kabupaten/Kota yang ada di provinsi Aceh dan time series dari tahun 2016 sampai tahun 2020.

Adapun tahapan analisis data yang dilakukan sebagai berikut :

1. Menentukan pemilihan variabel penelitian dari berbagai studi literatur

2. Melakukan eksplorasi data secara deskriptif

3. Melakukan pemodelan untuk menduga parameter regresi data panel yang sesuai

4. Melakukan pemilihan model regresi data panel meliputi uji signifikansi parameter, uji kesesuaian model dan koefisien determinasi $\left(R^{2}\right)$ sebagai berikut :

- Uji Chow

Dalam Baltagi (2005), Uji Chow digunakan untuk menguji antara model pengaruh umum (Common effect model/CEM) dan model pengaruh tetap (Fixed effect model/FEM).

Hipotesis yang diuji sebagai berikut :

$$
\begin{array}{ll}
H_{0}: \mu_{1}=\mu_{2}=\ldots=\mu_{i}=0 & (\mathrm{CEM}) \\
H_{1}: \text { minimal terdapat satu } \mu_{i} \neq 0 & \text { (FEM) }
\end{array}
$$


Statistik uji yang digunakan :

$$
F_{h i t}=\frac{(R R S S-U R S S) /(n-1))}{U R S S /(n t-n-p)}
$$

dengan:

RRSS = jumlah kuadrat galat terbatas dari model pengaruh umum.

URSS = jumlah kuadrat galat tidak terbatas dari model pengaruh tetap.

$n t=$ banyak amatan tiap waktu.

$p=$ banyak parameter.

Kriteria pengujian tolak $H_{0}$ jika $F_{h i t}>F_{(n-1, n t-n-p)}$ dan terima $H_{0}$ jika kondisi lainnya.

- Uji Hausman

Greene (2012), Uji Hausman digunakan untuk menguji antara model pengaruh acak (Random effect mode// REM) dengan model pengaruh tetap (Fixed effect mode/).

Hipotesisnya sebagai berikut:

$$
\begin{aligned}
& H_{0}:\left(\delta_{i t} \mid X_{i t}\right)=0 \text { (REM) } \\
& H_{1}:\left(\delta_{i t} \mid X_{i t}\right) \neq 0 \text { (FEM) }
\end{aligned}
$$

Statistik uji yang digunakan ::

$$
\chi_{\text {hit }}^{2}=(b-\beta)^{T} \operatorname{var}(b-\beta)^{-1}(b-\beta)
$$

dengan:

$\boldsymbol{b}=$ vektor dugaan parameter model pengaruh tetap.

$\boldsymbol{\beta}=$ vektor dugaan parameter model pengaruh acak.

Kriteria pengujian tolak $H_{0}$ jika $\chi_{\text {hit }}^{2}>\chi_{p}^{2}$ dan terima $H_{0}$ jika kondisi lainnya.

5. Melakukan penarikan kesimpulan berdasarkan model regresi data panel yang sesuai untuk mengetahui faktor-faktor yang berpengaruh terhadap tingkat kemiskinan di provinsi Aceh

\section{HASIL DAN PEMBAHASAN}

\subsection{Gambaran Umum Kemiskinan di Provinsi Aceh}

Provinsi Aceh memiliki 23 Kabupaten/Kota yang terbagi atas 18 Kabupaten dan 5 Kota. Kondisi tingkat kemiskinan Kabupaten/Kota di Aceh dapat dilihat pada Gambar 1. 


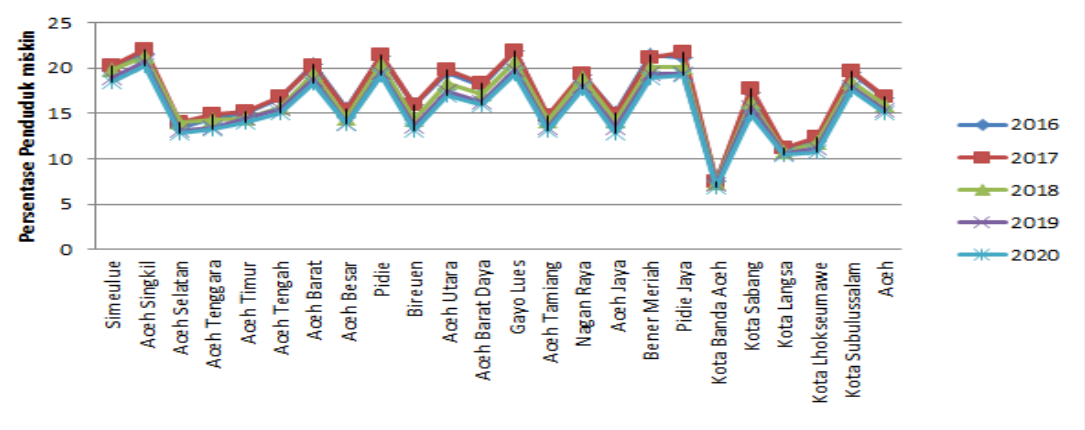

Gambar 1 : Tingkat Kemiskinan 23 Kabupaten/Kota di Provinsi Aceh dari Tahun 20162020

Pada Gambar 1 menunjukkan bahwa nilai sebaran data kemiskinan provinsi Aceh bervariasi selama kurun waktu 5 tahun. Tingkat kemiskinan Kabupaten/Kota di provinsi Aceh yang tertinggi terjadi pada tahun 2017 lalu mengalami penurunan di tahun-tahun berikutnya. Namun demikian, tingkat kemiskinan yang terjadi di provinsi Aceh untuk setiap Kabupaten/Kota dapat dikatakan masih cukup tinggi, kecuali Kota Banda Aceh. Hampir semua tingkat kemiskinan Kabupaten/Kota di provinsi Aceh masih berada diatas kemiskinan nasional Indonesia yang sebesar 10,19\%. Banda Aceh, Langsa dan Lhokseumawe merupakan daerah perkotaan yang konsisten memiliki tingkat kemiskinan dibawah kemiskinan provinsi dari tahun 2016-2020.

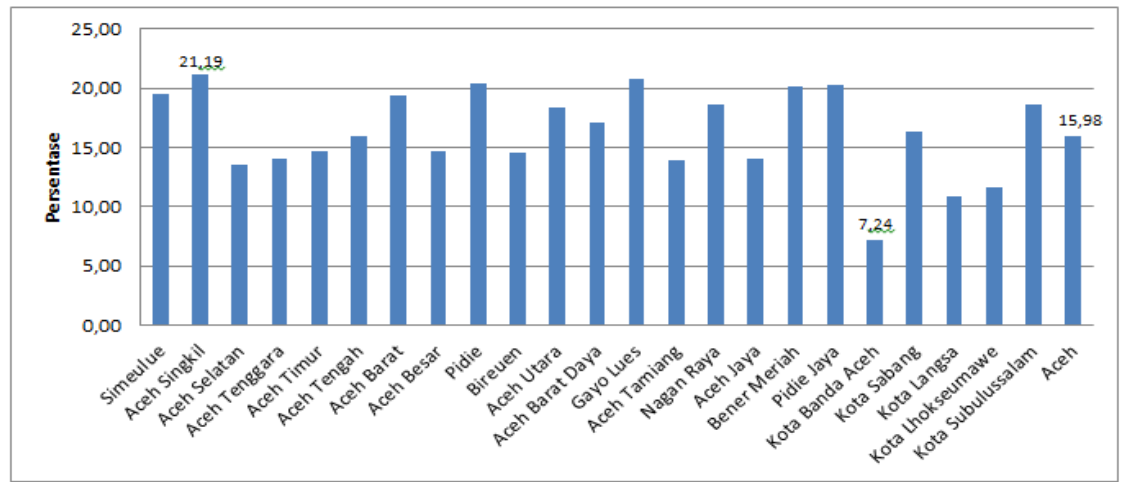

Gambar 2 : Rata-rata Tingkat Kemiskinan 23 Kabupaten/Kota di Provinsi Aceh dalam 5 tahun (2016-2020)

Lebih lanjut, keadaan tingkat kemiskinan Kabupaten/Kota di provinsi Aceh dapat dilihat pada Gambar 2 yang menunjukkan bahwa dalam kurun waktu 5 tahun, rata-rata tingkat kemiskinan di Aceh adalah sebesar 15,98 \%. Kabupaten Aceh Singkil merupakan daerah dengan tingkat kemiskinan tertinggi yaitu sebesar 21,19 \% jika dibandingkan dengan 
Kabupaten/Kota lainnya yang ada di Provinsi Aceh. Sedangkan tingkat kemiskinan yang terendah adalah Kota Banda Aceh. Kota Banda Aceh memiliki tingkat kemiskinan terendah dengan angka sebesar 7,24 \%. Hal itu disebabkan karena Kota Banda Aceh merupakan ibukota provinsi tempat berpusatnya semua kegiatan perekonomian dan pemerintahan tingkat provinsi. Jika dikategorikan kedalam 2 kelompok yaitu kelompok Kabupaten/Kota dengan tingkat kemiskinan dibawah dan diatas rata-rata provinsi, maka terdapat 12 Kabupaten/Kota yang berada diatas rata-rata kemiskinan provinsi dan terdapat 10 Kabupaten/Kota dibawah rata-rata kemiskinan provinsi.

\subsection{Model Regresi Data Panel Kemiskinan}

Pemodelan regresi data panel kemiskinan diawali dengan melakukan pengujian model yang tepat dengan membandingkan model CEM dan FEM dengan uji Chow dan selanjutnya membandingkan model FEM dan REM dengan uji Hausman untuk menentukan model yang sesuai. Hasil pengujian dengan uji Chow memperlihatkan bahwa nilai probabilitas ( $p$-value) dari uji Chi-square dan uji $\mathrm{F}$ statistik adalah 0,0000 yang berarti pada taraf nyata $\alpha=5 \%$ maka $\mathrm{p}$-value $<\alpha$ atau $0,0000<0,05$ sehingga hasil uji menyatakan bahwa $\mathrm{H}_{\mathrm{o}}$ ditolak dan $\mathrm{H}_{1}$ diterima sehingga model yang terpilih adalah fixed effect mode/ (FEM). Sementara dari hasil uji Hausman menunjukkan hasil nilai $\mathrm{p}$-value sebesar 0,0372 dengan tingkat taraf nyata $\alpha=$ $5 \%$ maka $\mathrm{p}$-value $<\alpha$ atau $0,0372<0,05$ yang berarti tolak $\mathrm{H}_{\mathrm{o}}$ sehingga model yang tepat adalah fixed effect model (FEM). Hasil uji Chow dan uji Hausman dapat dilihat pada Tabel 2.

Tabel 2 : Hasil Uji Chow dan Hausman

\begin{tabular}{|c|c|c|}
\hline Uji & Chow & Hausman \\
\hline Nilai Statistik & 92,007 & 10.198 \\
\hline Nilai $p$ - value & 0,0000 & 0.0372 \\
\hline
\end{tabular}

Tabel 3 menampilkan hasil pendugaan parameter model regresi data panel pengaruh tetap (FEM) dengan keempat variabel penjelas dan variabel respon tingkat kemiskinan. Variabel yang berpengaruh nyata terhadap tingkat kemiskinan pada taraf nyata $5 \%$ adalah indek pembangunan manusia (IPM), laju pertumbuhan penduduk (LPP) dan angka kesakitan (AK) Sedangkan variabel tingkat pengangguran terbuka (TPT) berpengaruh nyata pada taraf nyata $10 \%$ terhadap tingkat kemiskinan. Uji $F$ statistik menunjukkan nilai $p$-value $=0,0000<\alpha$ $=0,05$ yang berarti variabel penjelas secara bersama-sama mempengaruhi variabel respon tingkat kemiskinan.

Tabel 3 : Hasil pendugaan parameter regresi data panel dengan FEM

\begin{tabular}{lcccc}
\hline \multicolumn{1}{c}{ Variabel } & Koefisien & Galat baku & t-statistik & Nilai p-value \\
\hline IPM $\left(X_{1}\right)$ & -0.101930 & 0.029020 & -3.512359 & $0.0007^{*}$ \\
TPT $\left(X_{2}\right)$ & 0.065089 & 0.038061 & 1.710106 & $0.0908^{\star *}$ \\
\hline
\end{tabular}




\begin{tabular}{lllll}
\hline LPP $\left(\mathrm{X}_{3}\right)$ & -0.206063 & 0.046454 & -4.435867 & $0.0000^{*}$ \\
AK $\left(\mathrm{X}_{4}\right)$ & -0.103347 & 0.028758 & -3.593638 & $0.0005^{*}$ \\
\hline Prob(F-statistic) & 0.000000 & & & \\
R-squared & 0.971493 & & & \\
\hline
\end{tabular}

${ }^{*}$ ) nyata pada $\alpha=5 \%,{ }^{* *}$ ) nyata pada $\alpha=10 \%$,

Selain itu, Tabel 3 menunjukkan bahwa keempat variabel penjelas secara nyata memiliki pengaruh yang signifikan terhadap tingkat kemiskinan. Nilai koefisien determinasi $\left(R^{2}\right)$ yang dihasilkan dari model sebesar $97,14 \%$ yang berarti bahwa keragaman tingkat kemiskinan dapat dijelaskan $97,14 \%$ oleh variabel penjelas dalam model yaitu indek pembangunan manusia (IPM), laju pertumbuhan penduduk (LPP), angka kesakitan (AK) serta tingkat pengangguran terbuka (TPT). Sedangkan sisanya dijelaskan oleh variabel lainnya diluar model. Nilai $\mathrm{R}^{2}$ tersebut sangat tinggi sehingga dapat dikatakan bahwa regresi data panel model FEM sangat baik untuk memodelkan dan menjelaskan data tingkat kemiskinan di Aceh tahun 2016-2020. Berdasarkan tabel 3, maka dapat dituliskan model persamaan regresi data panel sebagai berikut :

$$
y_{i t}=25.0592-0.1019 X_{1 i t}+0.0650 X_{2 i t}-0.2060 X_{3 i t}-0.1033 X_{4 i t}+\varepsilon_{i t}
$$

\section{KESIMPULAN}

Berdasarkan pembahasan diatas disimpulkan bahwa model yang tepat untuk masalah kemiskinan di provinsi Aceh tahun 2016-2020 adalah model regresi data panel dengan pengaruh tetap (FEM) dengan variabel indek pembangunan manusia, angka kesakitan dan laju pertumbuhan penduduk merupakan faktor-faktor yang mempengaruhi terhadap kemiskinan di Aceh. Selain itu koefisien determinasi yang dihasilkan dari model regresi sangat baik yaitu sebesar $97.14 \%$.

\section{DAFTAR PUSTAKA}

[1]. Alifah, A. Yoza, H. and Asdi, Y., Faktor-Faktor yang Mempengaruhi Kemiskinan di Kota/Kabupaten Provinsi Sumatera Barat dengan Menggunakan Analisis Regresi Panel, Jurnal Sosial Humaniora Terapan, 9(1), 2019, pp. 53-61.

[2]. Andiny, P. and Mandasari, P., Analisis Pertumbuhan Ekonomi dan Kemiskinan Terhadap Ketimpangan di Provinsi Aceh, Jurnal Penelitian Ekonomi Akuntansi (Jensi), 1(2), 2017, pp. 196-210.

[3]. Baltagi, B. H., Econometrics Analysis of Panel Data [3rd ed.], England (GB), 2005, John Wiley and Sons.

[4]. BPS, Indikator Kesejahteraan Rakyat Provinsi Aceh 2020, Banda Aceh, 2020, BPS Provinsi Aceh. 
[5]. BPS, Perkembangan Indikator Sosial Ekonomi Provinsi Aceh 2020, Banda Aceh, 2020, BPS Provinsi Aceh

[6]. BPS, Provinsi Aceh dalam Angka 2021, Banda Aceh, 2021, BPS Provinsi Aceh.

[7]. Ferezagia, D. V., Analisis Tingkat Kemiskinan di Indonesia, Jurnal Sosial Humaniora Terapan, 1(1), 2018, pp. 1-6.

[8]. Greene, W. H., Econometric Analysis [7rd ed.], New York, 2012, Prentice Hall.

[9]. Pulungan, M. H., Analisis Faktor-Faktor yang Mempengaruhi Tingkat Kemiskinan di Provinsi Sumatera Utara [Tesis], Bogor, 2016, IPB.

[10]. Zuhdiyaty, Noor, and Kaluge, David., Analisis Faktor - Faktor Yang Mempengaruhi Kemiskinan Di Indonesia Selama Lima Tahun Terakhir (Studi Kasus Pada 33 Provinsi), JIBEKA, 11(2), 2017, pp. 27-31. 